\title{
Perancangan Sistem Informasi Geografis Lokasi Objek Wisata Di Kota Lubuklinggau Berbasis Android
}

\author{
Joni Karman1, Hardi Mulyono² \\ 1,2 Program Studi Sistem Informasi, STMIK Musirawas, Lubuklinggau \\ jonikarman@univbinainsan.ac.id
}

\begin{abstract}
The Problem In Finding and acces a tourism location in Lubuklinggau, be a primary problem, Especially for tourism or visitoe or tourism from other place in Indonesia. We know that the technology more being advance, but this case make we to improve our potency in Lubuklinggau. Hopely this application which will be made, will appliance the web technology service, in order to the information about tourism will be up to date and to solve this problem the researcher use digital map model approach or SIG based on Android by using Google Maps as the map digital. The method which used in tihs research is UML (Unifide Modelling Language), PHP Program, Java and database Mysql as the data saving geografic information system (GIS) tourism has two programs they are, administration programe for processing tourism data base on web and programe for the user, we use Android aplication. Geografic information system has a goal to give an easy and faster information about tourism in Lubuklinggau
\end{abstract}

Keywords: Geographic Information System, Tourist Attraction, Android

\begin{abstract}
Abstrak
Masalah dalam pencarian dan akses menuju sebuah lokasi wisata wilayah kota Lubuklinggau menjadi sebuah permasalahan utama, terutama kepada tourism atau pengunjung atau wisatawan yang datang dari wilayah lain yang ada di Negara Indonesia ini. Kita ketahui bahwa saat ini teknologi semakin kian pesat maju baik kita sadari dan tidak kita sadari, namun hal ini yang menjadikan kita untuk lebih mengembangkan serta memaksimalkan objek wisata yang ada di kota Lubuklinggau. Sehingga diharapkan nantinya aplikasi yang dirancang ini akan menerapkan teknologi web service, sehingga informasi tentang wisata selalu terbarui. Serta untuk mengatasi masalah tersebut peneliti menggunakan pendekatan pada model pemetaan digital berupa SIG dengan berbasis Android dengan memanfaatkan google maps sebagai peta digital. Metode yang di gunakan dalam melaksanakan penelitian ini adalah dengan menggunakan desain sistem UML (Unifed Modeling Language), dengan bahasa pemrograman PHP, java dan database MySQL sebagai databasenya. Sistem Informasi Geografis (SIG) objek wisata alam ini memiliki dua program yaitu program admin untuk mengelola data wisata kita menggunakan berbasis web dan untuk program user kita menggunakan aplikasi Android. Sistem informasi geografis ini bertujuan untuk memberikan kemudahan, kenyamanan dan kecepatan kepada masyarakat dalam memperoleh informasi-informasi tentang objek wisata yang ada di Kota Lubuklinggau.
\end{abstract}

Kata kunci: Sistem Informasi Geografis, Objek Wisata, Android

\section{PENDAHULUAN}

Perkembangan teknologi informasi dan komunikasi telah berkembang sangat pesat sehingga perkembangannya dapat dirasakan hampir di seluruh negara di dunia dari tahun ke tahun. Dengan adanya perkembangan teknologi informasi dan komunikasi ini telah membawa perubahan pola dan gaya hidup bagi setiap warga dunia yang mengalaminya. Perubahan hidup disini terjadi karena perkembangan teknologi informasi dan komunikasi yang terjadi 
ternyata memiliki dampak yang sangat penting dan berarti bagi kehidupan manusia.

Objek-objek wisata yang ada di Kota Lubuklinggau ini sangat potensial untuk dikembangkan. Daerah ini memiliki obyek-obyek wisata yang sangat indah dan menawan, baik wisata alam, sejarah maupun budaya. Penyampaian informasi objek-objek wisata di Kota Lubuklinggau masih belum maksimal, seperti pemberian sebaran brosur dan pamflet itu pun dilakukan hanya jika ada wisatawan yang ingin datang berkunjung ke suatu obyek wisata yang dikunjunginya. Pengenalan akan objek-objek wisata yang ada di Kota Lubuklinggau diharapkan dapat meningkatkan jumlah wisatawan untuk datang ke kota ini serta dapat mengingkatkan penghasilan masyarakat setempat.

Media Informasi yang diadakan oleh Dinas Kebudayaan dan Pariwisata Kota Lubuklinggau tersebut sangat terbatas. Hal ini membuat masyarakat luas yang ingin melakukan wisata di Kota Lubuklinggau tidak bisa mendapatkan informasi tentang kepariwisataan dengan cepat dan secara detail karena harus datang ke kantor Dinas Kebudayaan dan Pariwisata secara langsung. Selain itu informasi yang diberikan lewat media pamflet atau brosur sangat kurang menarik dan informatif karena hanya ditampilkannya nama serta keterangan sejarah dari obyek wisata yang dapat dikunjungi tanpa menampilkan lokasi dari objek wisata tersebut.

Pemerintah Kota Lubuklinggau yang memiliki program Visit Lubuklinggau 2015 mempromosikan obyek wisata melalui website egovernment yakni yang beralamat www.lubuklinggau.go.id sedangkan Dinas Kebudayaan dan Pariwisata Kota Lubuklinggau belum memiliki website sendiri. Saat ini Peta wisata juga belum dimiliki Dinas Kebudayaan dan Pariwisata Kota Lubuklinggau yang mana membuat para wisatawan tidak mengetahui secara detail lokasi wisata yang ingin dikunjunginya. Maka dari itu, dalam penelitian ini akan dibangun media informasi untuk mengetahui lokasi sekaligus informasi tentang daerah obyek wisata yang akan dikunjungi sebagai media alternatif untuk menginformasikan pariwisata di Kota Lubuklinggau agar bisa dinikmati masyarakat luas yaitu dengan melalui fasilitas internet.

Melihat kondisi tersebut, maka penulis tertarik untuk membuat sistem yang dapat memberikan informasi tentang letak objek wisata yang ada di Kota Lubuklinggau. Untuk merealisasikan hal tersebut peneliti melakukan penelitian permasalahan tersebut pada penelitian mengenai "Sistem Informasi Geografis Pemetaan Letak Objek Wisata Berbasis Android (Studi Kasus Dinas Pariwisata Kota Lubuklinggau)".

\section{METODOLOGI PENELITIAN}

\subsection{Perancangan}

Perancangan sistem adalah tahap yang dilakukan setelah melakuka analisis sitem, pendefinisian kebutuhan-kebutuhan sistem yang akan dibangun, dan di persiapkan untuk merancang bangun implementasi sitem dengan menggambarkan sistem yang akan dibangun [1]. Perancangan sistem 
dibangun oleh dua sisi program yang terdirii dari program server admin dan program client user. Program server admin terdiri dari webservice, database MySQL sedangkan dari program client user terdiri dari aplikasi mobile GIS. Data survey yang terkait dengan data atribut diolah dan dimasukkan ke dalam database dengan menggunakan MySQL. Serta data hasil dari digitasi pada mapinfo dengan format .json untuk di proses kedalam bahasa Android .xml.

\subsection{Sistem}

Sistem dapat didefinisikan sebagai sekumpulan objek, ide berikut keterkaitannya di dalam mencapai tujuan. Dengan kata lain sistem adalahh sekumpulan komponen (sub-sistem fisik \& non-fisik/logika) yang saling berhubungan satu sama lainnya dan bekerja sama untuk mencapai suatu tujuan [2].

Sistem adalah suatu jaringan kerja dari prosedur-prosedur yang saling berhubungan, berkelompok dan bekerja sama untuk melakukan kegiatan pencapaian sasaran tertentu [3]. Dari beberapa pengertian sistem diatas dapat disimpulkan bahwa sistem adalah sekumpulan elemen yang saling terhubung satu sama lain dan bekerja sama untuk mencapai suatu tujuan.

\subsection{Sistem Informasi Geografis}

Sistem Informasi Geografis adalah sistem informasi yang dirancang untuk bekerja dengan data yang tereferensikan secara spasial / geografis. Dengan kata lain SIG merupakan sistem basisdata dengan kemampuan khusus dalam menangani data tereferensi secara spasial; selain merupakan sekumpulan operasi yang dikenal terhadap data tersebut [2]. SIG adalah kumpulan yang terorganisir dari perangkat keras komputer, perangkat lunak, data geografis, metode, dan personil yang dirancang secara efisien untuk memperoleh, menyimpan, memperbaharui, memanipulasi, menganalisis, dan menampilkan semua bentuk informasi yang bereferensi geografis [3].

Dari beberapa pengertian sistem informasi geografis diatas dapat disimpulkan bahwa sistem informasi geografis adalah sistem yang dirancang untuk bekerja dengan data bereferensi geografis baik berupa data spasial dan data non spasial.

\subsection{Pengertian Android Studio}

Android studio adalah IDE (Integrated Development Environment) resmi untuk pengembangan aplikasi Android dan bersifat open source atau gratis. Peluncuran Android Studio ini diumumkan oleh Google pada 16 mei 2013 pada event Google I/O Conference untuk tahun 2013. Sejak saat itu, Android Studio mengantikan Eclipse sebagai IDE resmi untuk mengembangkan aplikasi Android.

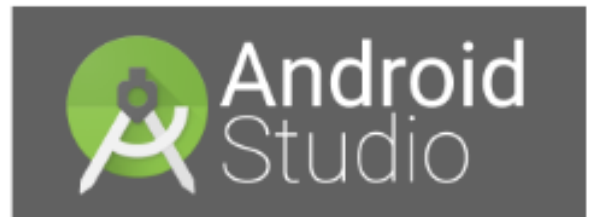

Gambar 1.Android Studio 
Android studio sendiri dikembangkan berdasarkan IntelliJ IDEA yang mirip dengan Eclipse disertai dengan ADT plugin (Android Development Tools). Android studio memiliki fitur :

a. Projek berbasis pada Gradle Build

b. Refactory dan pembenahan bug yang cepat

c. Tools baru yang bernama "Lint" diklaim dapat memonitor kecepatan, kegunaan, serta kompetibelitas aplikasi dengan cepat.

d. Mendukung Proguard and App-signing untuk keamanan.

e. Memiliki GUI aplikasi Android lebih mudah

f. Didukung oleh Google Cloud Platfrom untuk setiap aplikasi yang dikembangkan.

\subsection{Pengertian Google Maps}

Google Maps merupakan sebuah layanan peta dunia virtual berbasis web yang disediakan oleh Google. Layanan ini gratis dan dapat ditemukan di http://maps.google.com. Browsing peta dapat dilakukan dengan mudah, dan data peta selalu diperbaharui secara berkala. Setiap orang bebas memperbaharui konten, jika belum pernah melalui jalan yang ada di peta, dapat menambah dengan bebas. Tidak sedikit orang dan perusahaan komersial telah ikut menempatkan data untuk keperluan masing-masing [5].

\section{HASIL DAN PEMBAHASAN}

Penelitian ini menggunakan metode pengembangan sistem dengan metode Waterfall, Alasan digunakan metode ini dikarenakan langkah-langah metode waterfall sesuai dengan rancangan peneliti. Dimana dalam pengembangan ini peneliti merancang dan membangun sistem secara bertahap. Adapun tahapan yang dilakukan dalam melakukan pelaksanaan penelitian ini adalah sebagai berikut:

\subsection{Analisis Sistem}

Tahap analisa, pada tahap ini peneliti menganalisa sistem yang telah berjalan selama ini, yakni cara promosi obyek wisata dengan cara melalui media cetak maupun pamphlet serta belum tersedianya sistem aplikasi berbasis Android yang memberikan informasi wisata dan untuk pengelolaan obyek wisata di kota Lubuklinggau.

\subsection{Desain Sistem}

Pada tahap ini peneliti membuat desain dari sistem yang akan dibuat berupa struktur data, arsitektur perangkat lunak menggunakan diagram bantu $(U M L)$, pemodelan data survey yang diolah dan disimpan dalam penyimpana MySQL untuk ditampilkan pada Peta Digitasi yang memanfaatkan google Maps, dan mampu menghasilkan desain tampilan antar muka interface menggunakan PHP untuk program web admin dan java (Android studio) untuk program user, yang akan diimplementasikan menjadi program pada tahap selanjutnya. 


\subsubsection{Use case diagram}

Use case diagram berfungsi untuk menggambarkan dan memodelkan serta mengorganisasi pada sistem informasi geografis lokasi objek wisata di kota Lubuklinggau, dimana pembuatannya terdiri atas 4 aktor yaitu admin, operator pariwisata, pimpinan dan pengunjung. Sehingga apa yang diperbuat oleh aktor tersebut pada sistem terlihat dengan jelas yang di sajikan pada gambar 2.

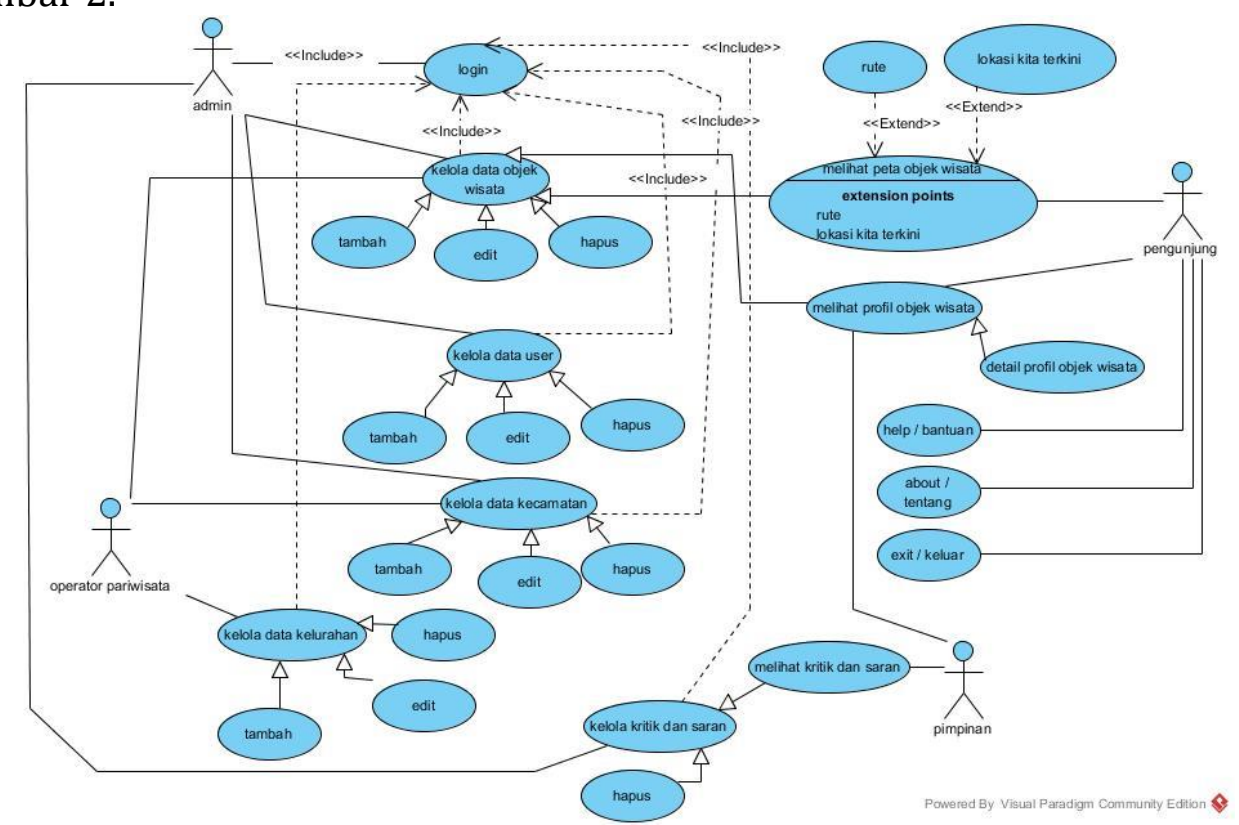

\subsubsection{Class diagram}

Gambar 2.Use case diagram

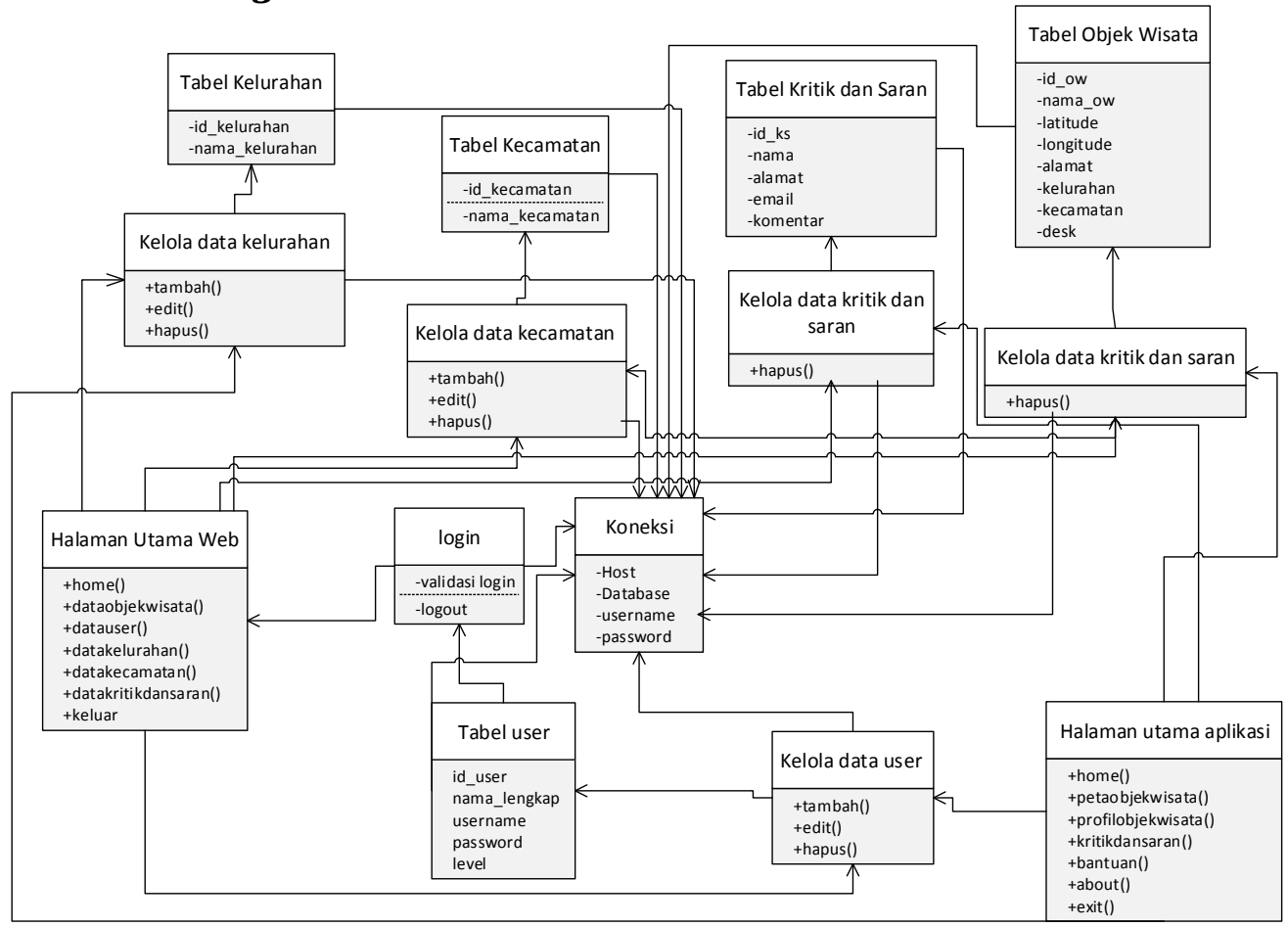

Gambar 3. Class Diagram 


\subsubsection{Database}

Rancangan database yang akan dibuat antara lain:

Tabel 1. Desain Tabel admin

\begin{tabular}{|c|c|c|c|c|}
\hline No & Field & Type & Width & Keterangan \\
\hline 1 & id_user & Varchar & 15 & Primary Key \\
\hline 2 & nama_lengkap & Varchar & 255 & \\
\hline 3 & username & Varchar & 50 & \\
\hline 4 & password & Varchar & 50 & \\
\hline 5 & level & Varchar & 25 & \\
\hline
\end{tabular}

Tabel 2. Desain Tabel kelurahan

\begin{tabular}{|c|c|c|c|c|}
\hline No & Field & Type & Width & Keterangan \\
\hline 1 & id_kelurahan & int & 15 & Primary Key \\
\hline 2 & nama_kelurahan & varchar & 255 & \\
\hline
\end{tabular}

Tabel 3. Desain Tabel kecamatan

\begin{tabular}{|c|c|c|c|c|}
\hline No & Field & Type & Width & Keterangan \\
\hline 1 & id_kecamatan & int & 15 & Primary Key \\
\hline 2 & nama_kecamatan & varchar & 255 & \\
\hline
\end{tabular}

Tabel 4. Desain Tabel objek_wisata

\begin{tabular}{|c|c|c|c|c|}
\hline No & Field & Type & Width & Keterangan \\
\hline 1 & id_ow & int & 15 & Primary Key \\
\hline 2 & nama_ow & varchar & 100 & \\
\hline 3 & latitude & varchar & 100 & \\
\hline 4 & longitude & varchar & 100 & \\
\hline 5 & alamat & varchar & 255 & \\
\hline 6 & kelurahan & varchar & 255 & \\
\hline 7 & kecamatan & varchar & 255 & \\
\hline 8 & desk & varchar & 255 & \\
\hline
\end{tabular}

Tabel 5. Desain Tabel kritik_saran

\begin{tabular}{|c|c|c|c|c|}
\hline No & Field & Type & Width & Keterangan \\
\hline 1 & id_ks & int & 15 & Primary Key \\
\hline 2 & nama & varchar & 255 & \\
\hline 3 & alamat & varchar & 255 & \\
\hline 4 & email & varchar & 255 & \\
\hline 5 & komentar & varchar & 155 & \\
\hline
\end{tabular}

\subsection{Hasil}

Setelah melakukan perancangan sistem selesai dikerjakan langkah selanjutnya adalah melakukan pembuatan sistem. Untuk mengelola data objek wisata dengan menggunakan backend berbasis web mobile dan PC maka proses log in terlebih dahulu. 


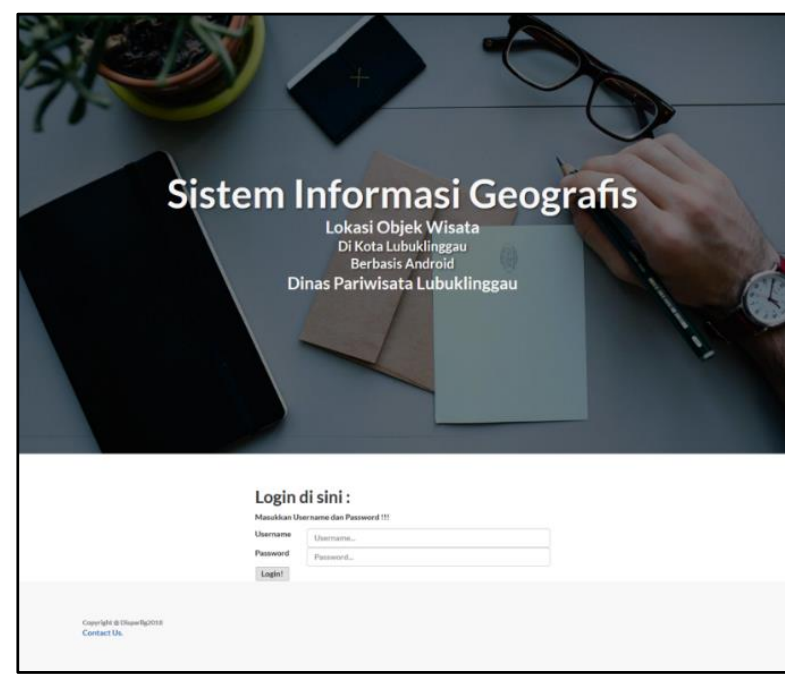

Gambar 4. Tampilan Log In
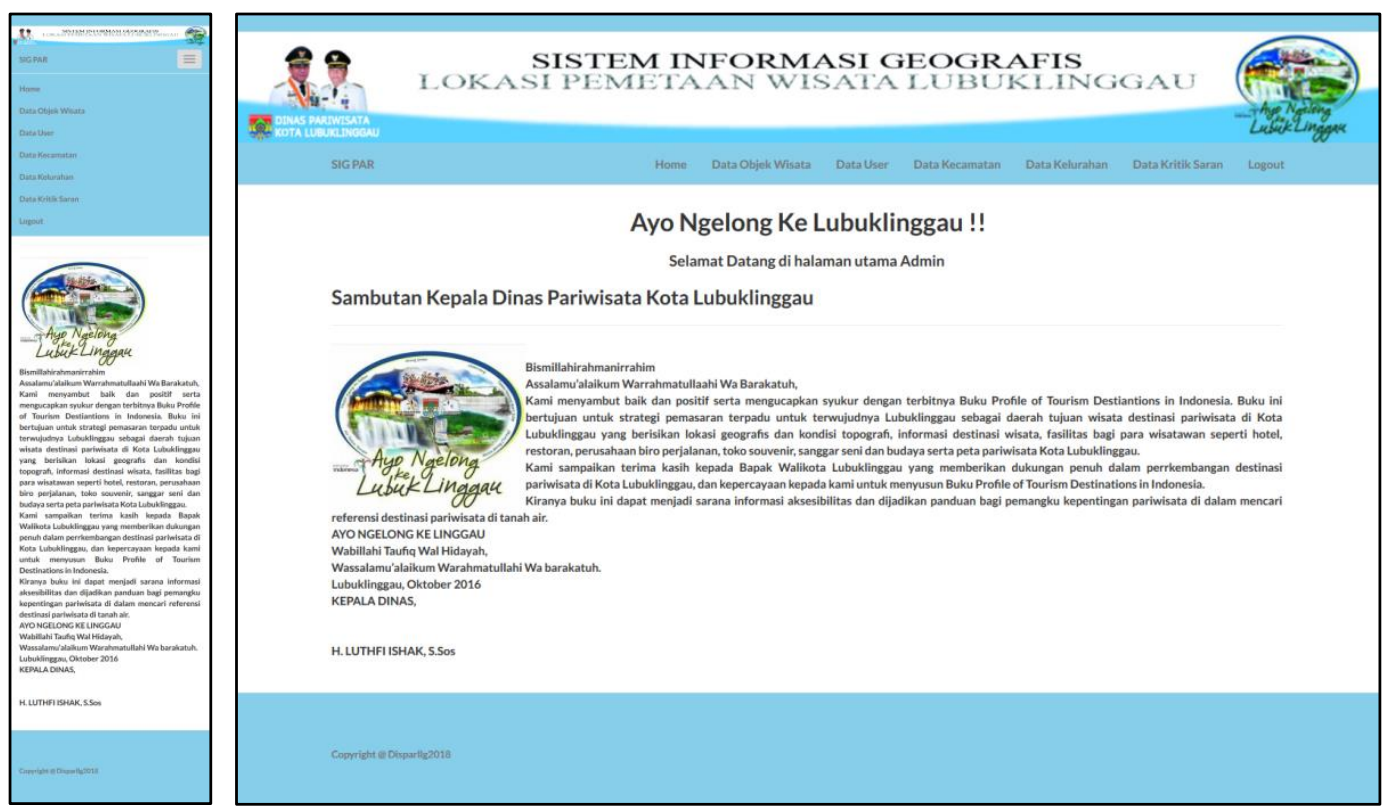

Gambar 5. Tampilan Halaman Utama

Dengan menggunakan user Admin yang dijadikan sebagai super user, maka dapat melakukan untuk pengelolaan data user, data objek wisata, data kelurahan, data kecamatan, data kritik dan saran. 


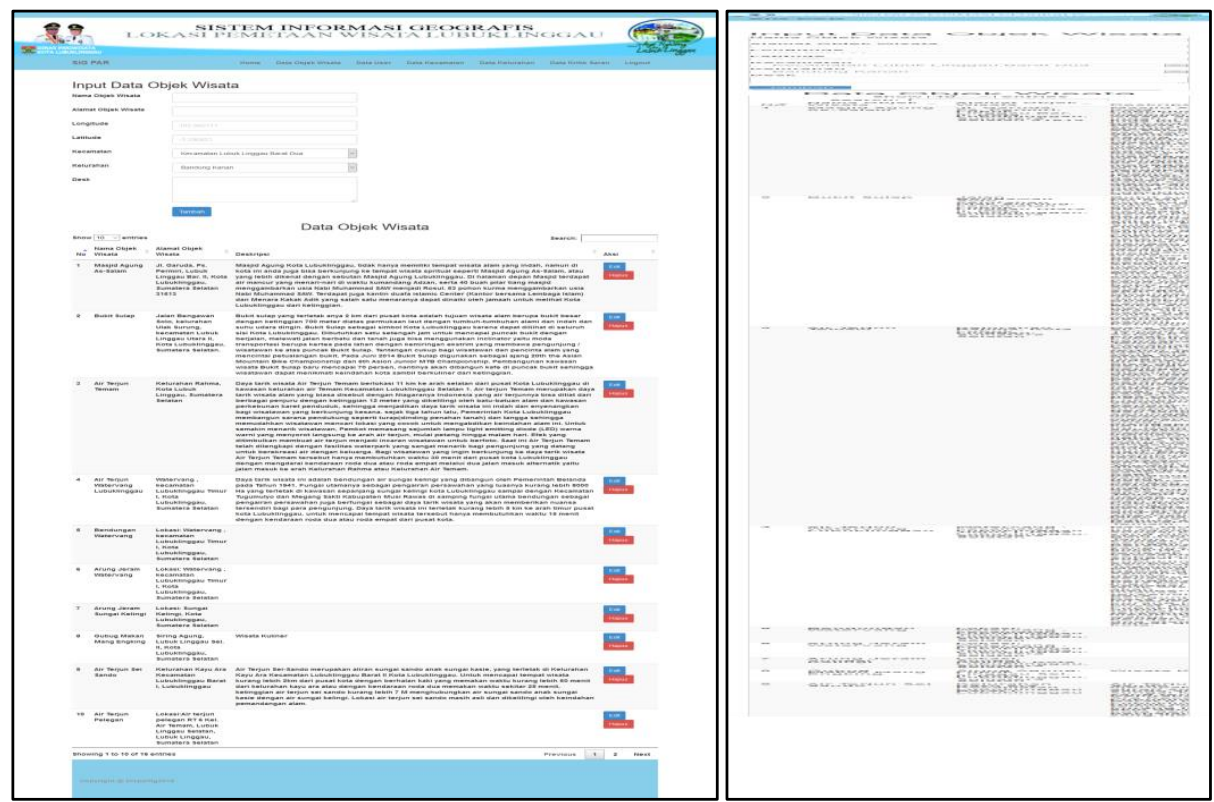

Gambar 6. Tampilan Data Objek Wisata

Dalam fungsi utama sig ini diciptakan menggunakan platform Android maka pengguna/masyarakat dapat menginstal aplikasinya di smartphone nya masing masing, dengan menggunakan koneksi internet serta bantuan fitur utama dari google maps. Aplikasi ini menampilkan splashscreen, halaman utama aplikasi, halaman peta objek wisata, rute dari marker peta objek wisata, profil objek wisata, detail profil objek wisata, kritik dan saran untuk aplikasi, bantuan / petunjuk penggunaan aplikasi, about / tentang aplikasi, serta exit dari aplikasi seperto pada gambar 6 untuk splashscreen aplikasi, 7 untuk halaman utama, 8 untuk halaman peta objek wisata, 9 untuk rute dari marker peta objek wisata, 10 untuk profil objek wisata, 11 untuk detail profil objek wisata, 12 untuk krtik dan saran, 13 untuk petunjuk penggunaan aplikasi, 14 untuk tentang aplikasi, 15 untuk keluar dari aplikasi.

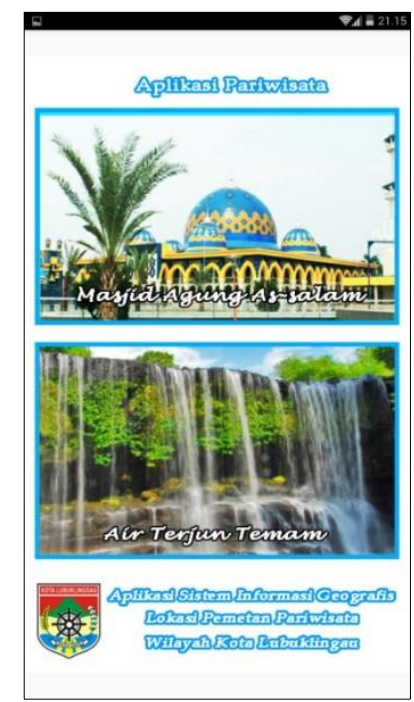

Gambar 7. Tampilan Splashscreen Aplikasi Android 


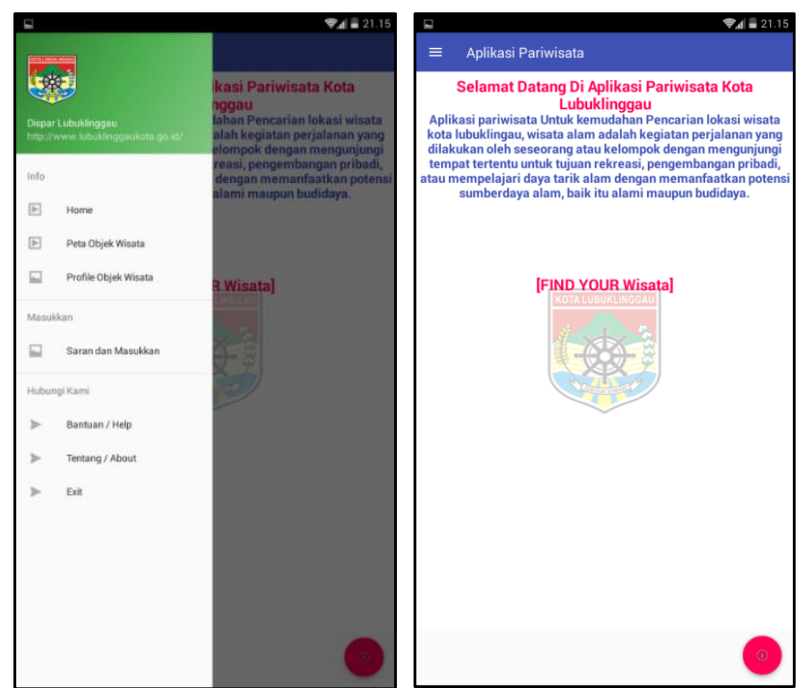

Gambar 8. Tampilan Halaman utama Aplikasi Android

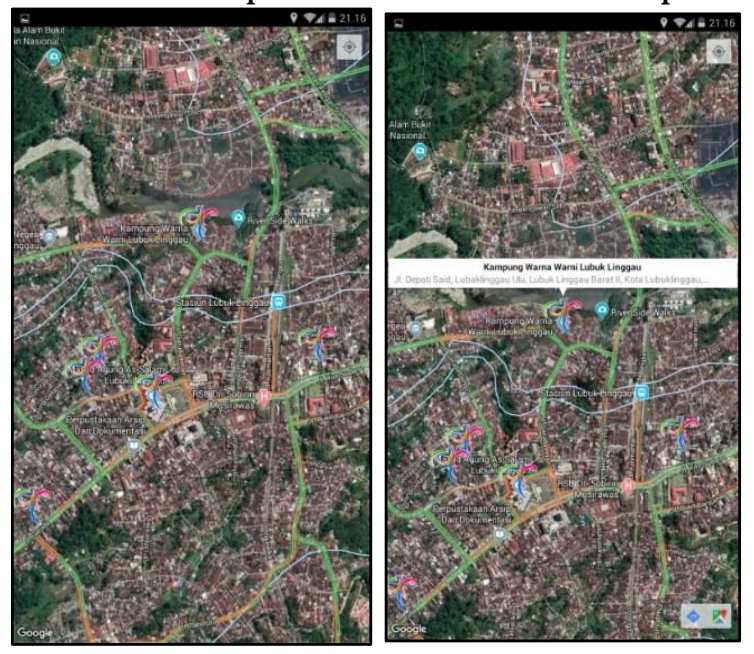

Gambar 9. Tampilan Halaman peta objek wisata Aplikasi Android

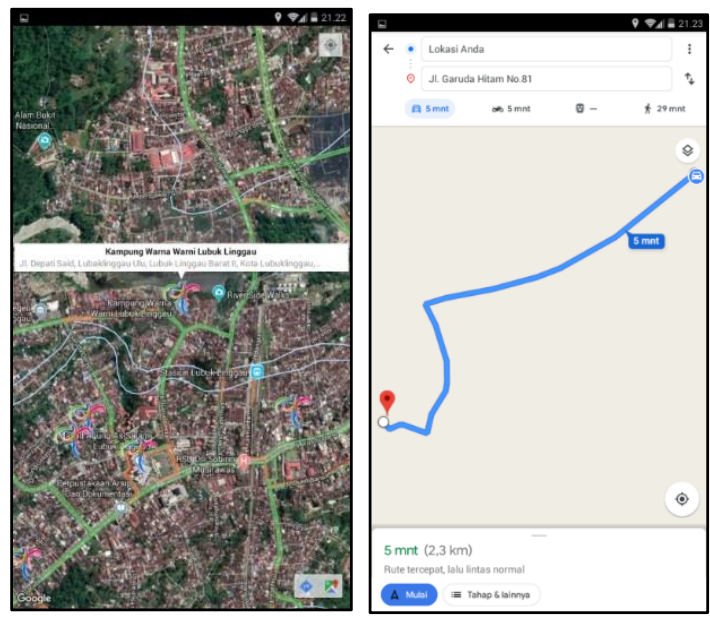

Gambar 10. Tampilan Halaman rute dari marker peta objek wisata Aplikasi Android 


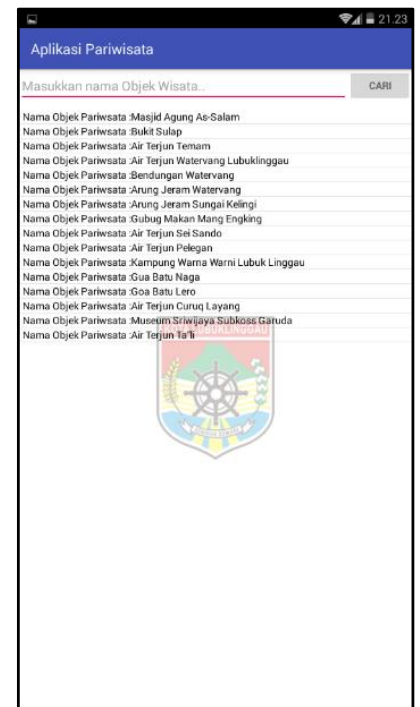

Gambar 11. Tampilan Halaman Profil Objek Wisata Aplikasi Android

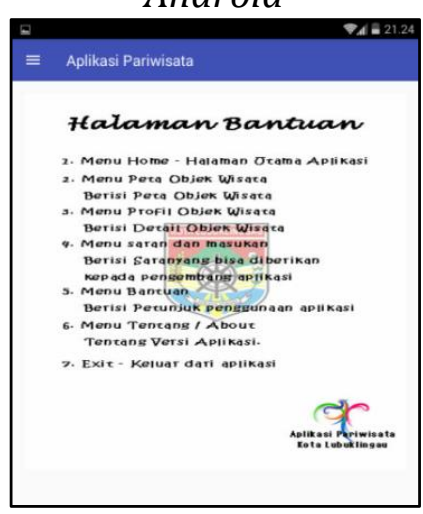

Gambar 14. Tampilan Halaman Petunjuk Penggunaan Aplikasi Android

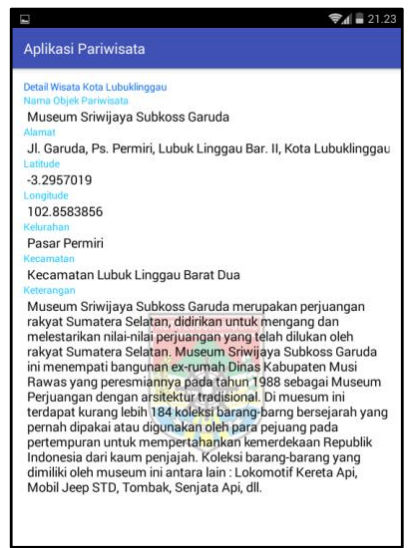

Gambar 12. Tampilan Halaman Detail Profil Objek Wisata Aplikasi Android

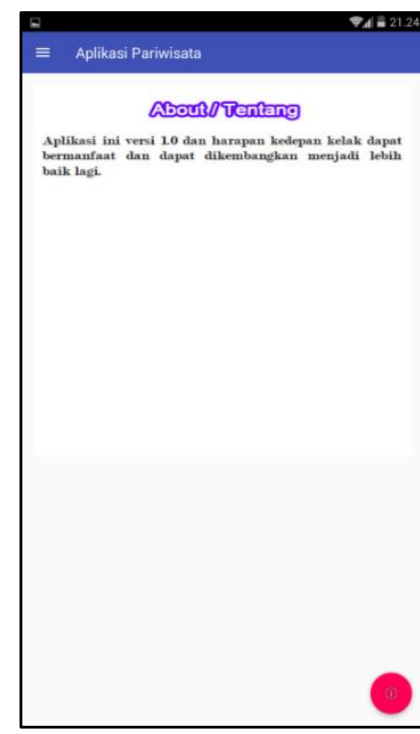

Gambar 15. Tampilan Halaman Tentang Sistem Informasi Geografis Aplikasi Android

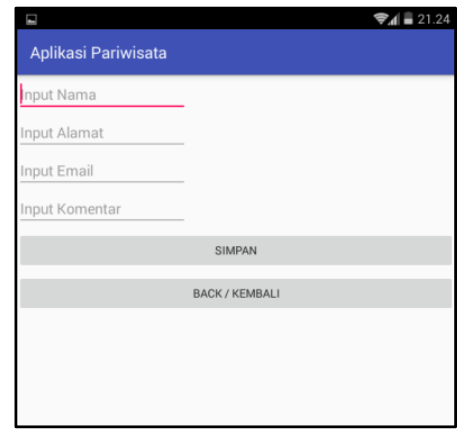

Gambar 13. Tampilan

Halaman Kritik dan Saran Aplikasi Android

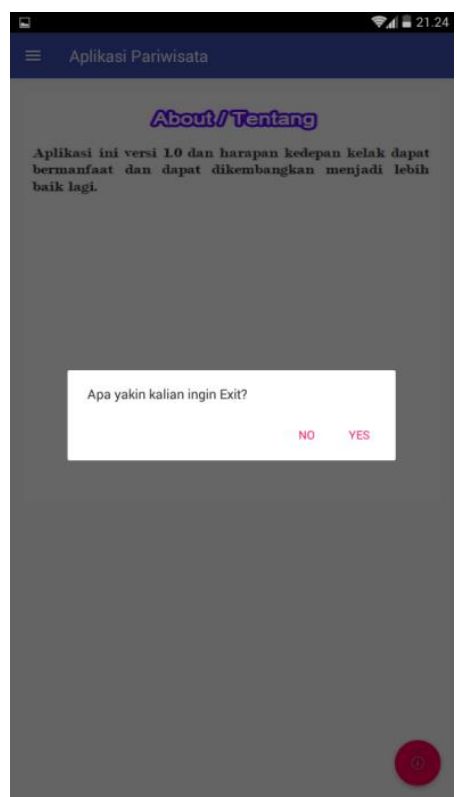

Gambar 16. Tampilan Halaman keluar dari Aplikasi Android

\subsection{Pembahasan}

Penginputan data objek wisata dari operator ke database dapat dilakukan menggunakan personal computer (PC) atau pun bisa juga dengan menggunakan web mobile yang kemudian hasilnya bisa langsung di tampilkan ke dalam bentuk program Android. Pada saat ini sistem infromasi geografis lokasi difungsikan untuk memetakan lokasi pemetaan objek wisata yang ada di kota Lubuklinggau secara realtime dengan koneksi internet serta fitur 
tambahan dari google maps. Dengan adanya sistem informasi lokasi geografis lokasi pemetaan objek wisata memberikan kemudahan dan kecepatan bagi masyarakat kota lubuklinggau maupun masyarakat diluar kota lubuklinggau dalam memperoleh informasi mengenai objek wisata yang ada di Kota Lubuklinggau.

\section{SIMPULAN}

Dari hasil dan pembahasan dapat di tarik kesimpulan sementara dari penelitian ini yaitu :

a. Hasil inputan yang dilakukan oleh admin/operator ke database server dan di tampilkan di aplikasi user berupa program aplikasi sig Android dapat di lakukan secara realtime.

b. Penggunaan aplikasi sig lokasi pemetaan objek wisata ini adalah untuk memberikan kemudahan dan kecepatan kepada masyarakat yang ada di Kota Lubuklinggau maupun masyarakat diluar Kota Lubuklinggau dalam memperoleh informasi mengenai objek wisata yang ada di Kota Lubuklinggau

\section{DAFTAR PUSTAKA}

[1] Jogiyanto, Analisis dan Desain Sistem. Yogyakarta: Andi, 2010.

[2] E. Prahasta, Sistem informasi geografis: konsep-konsep dasar (perspektif geodesi dan geomatika). Bandung: Informatika, 2014.

[3] Riyanto, Prilnali, and Hendi, Pengembangan aplikasi sistem informasi geografis berbasis desktop dan web. Yogyakarta: Gava Media, 2009.

[4] Wikipedia Ensiklopedia Bebas, "Obyek wisata," Wikipedia Ensiklopedia Bebas,. 2018.

[5] Riyanto, Sistem Informasi Geografis Berbasis Mobile. Yogyakarta: Gava Media, 2010. 